\title{
Animasi Interaktif Untuk Pembelajaran Matematika Dasar
}

\author{
Siti Kusnul Wulandari', Eka Rini Yulia ${ }^{2}$ \\ ${ }^{1}$ Manajemen Informatika, AMIK BSI Jakarta \\ e-mail: wulandarikusnul@gmail.com \\ ${ }^{2}$ Sistem Informasi, STMIK Nusa Mandiri \\ e-mail: eka.erl@nusamandiri.ac.id
}

\begin{abstract}
Adobe Flash CS4 is software that is widely used by web and graphic professionals because of its ability to support multimedia, a combination of graphics, animation, sound and interactivity for internet users. The interactive module application has the advantages of interesting facilities such as music, animation and quiz questions consisting of text. Researchers tried a little in the world of education by making interactive animations for basic mathematics learning. The researcher made this interactive animation in the hope that it could help this research be useful and useful in counting and memorizing numbers. This Interactive Module is also equipped with quiz questions so users can use their abilities.
\end{abstract}

Keywords: Animation, Basic Mathematics Learning, Adobe Flash CS4

\section{PENDAHULUAN}

Pemanfaatan ilmu pengetahuan dan teknologi berkembang dengan sangat cepat dan menghasilkan inovasi-inovasi baru yang harus diimbangi dengan kemampuan beradaptasi terhadap teknologi tersebut. Salah satu dari bidang tersebut adalah teknologi informasi yang berbasis komputer multimedia. Hal ini terus menyeret dan memacu kita untuk masuk dalam lingkaran alam kecanggihan tersebut. Oleh karena itu kita berkarya untuk menghasilkan sesuatu yang berguna bagi diri sendiri maupun bagi orang lain yang membutuhkan informasi.

Informasi mengenai Pendidikan tentunya kita tahu bahwa pendidikan sekarang sangat kurang diminati anak- anak apalagi dalam membaca dan belajar. Demikian pula pendidikan yang diharuskan membaca dan menghafal. Oleh karena itu dibutuhkan suatu alat penunjang belajar yang dapat mengakomodasi masalah.

Namun bagi anak yang belum mengenal angka dengan benar, peneliti sengaja menyajikan angka berupa gambar dan suara supaya anak-anak usia 7 (tujuh) tahun sampai 9 (sembilan) tahun setingkat dengan sekolah dasar kelas satu sampai kelas tiga bisa mempelajarinya dengan melihat angka yang anak-anak anggap sulit untuk menghafalnya. Dilengkapi juga dengan contohcontoh soal sederhana yang bisa dikerjakan anakanak dengan mudah. Penyajian yang sederhana dan praktis memudahkan anak- anak sekolah dasar antara kelas satu sampai kelas tiga untuk mempelajarinya.
Maksud dari tujuan penelitian ini adalah :

a. Diharapkan dengan adanya aplikasi ini dapat membantu anak-anak dari kelas 1-3 Sekolah Dasar. Karena aplikasi ini disajikan dengan sangat praktis dan sistematis serta penjelasan yang sederhana sehingga sangat mudah untuk dimengerti.

b. Peneliti ingin membuat suatu program animasi interaktif yang diharapkan dapat mempelajari dan memahami program animasi secara praktis, cepat mudah sesuai dengan kebutuhan serta mempermudah cara belajar para pengguna.

Adapun tujuan dari penelitian ini adalah membantu anak-anak dari kelas $1-3 \quad$ Sekolah Dasar untuk memahami dan mempelajari tentang matapelajaran matematika yang kadang diangkap sulit oleh mereka.

1. Dalam penelitian ini peneliti membahas Pendidikan Matematika Dasar untuk kelas satu sampai kelas tiga sekolah dasar.

2. Peneliti membatasi ruang lingkup pembahasan mulai dari pengenalan angka dan pengucapannya dengan baik dan benar disertai latihan soal sederhana. Beberapa aplikasi tools yang digunakan dalam game pendidikan ini ekstensi beberapa file, yaitu file gambar dengan ekstensi jpg, dan gif sedangkan file suara dengan ekstensi mp3. 


\section{METODOLOGI PENELITIAN}

Dalam penelitian ini diperlukan data-data yang mendukung sebagai bahan masukan yang akan digunakan dalan penyusunan sehingga dapat mendukung kebenaran uraian dan pembahasan yang dapat dikaji dan ditelaah sebagai mestinya karya tulis ilmiah.

\section{A. Teknik pengumpulan}

1. Observasi

Dalam hal ini peneliti mengamati beberapa template animasi flash yang sesuai dengan konsep dan judul pada penelitian ini.

2. Studi Pustaka

Peneliti melakukan studi pustaka sebagai pendukung untuk mendapatkan berbagai macam informasi dengan cara mencari buku-buku yang berhubungan dengan pembahasan yang diperlukan untuk dijadikan sebagai referensi dalam penulisan penelitian ini.

Animasi sudah menjadi bagian dari suatu tampilan halaman web, presentasi, maupun yang lainnya. Hal ini dikarenakan animasi dapat memfokuskan pandangan audien pada tampilannya. Fakta tersebut telah menjadikan animasi sebagai suatu hal yang umum dan sering dijumpai.

Menurut Jibril (2011)“animasi adalah gerakan obyek yang diatur sedemikian rupa sehingga dapat bergerak sesuai keinginan animator". Menurut Andi (2009)“animasi adalah sebuah gerakan obyek maupun teks yang diatur sedemikian rupa sehingga kelihatan hidup".

Menurut Ees (2008)“konsep adalah sebuah pemikiran awal". Konsep ini akan menentukan hasil akhir sebuah ide yang belum terealisai sehingga designer dapat melihat gambaran singkat mengenai hasil akhir yang akan dihasilkannya.

Menurut Jibril (2011)“ ActionScript adalah perintah yang diletakkan pada suatu frame atau obyek yang berfungsi menjalankan suatu perintah atau aksi tertentu dengan menggunakan script".

Membuat animasi, hal yang biasa dilakukan terlebih dahulu adalah membuat satu per satu bagian tertentu, atau istilahnya frame per frame. Hal ini merupakan hal yang sangat berat dalam membuat animasi, mengingat kita harus memikirkan bagaiman bagaimana desain atau bagian animasi yang kita buat tersebut supaya benar-benar mendapatkan hasil yang sempurna jika disatukan.

Pada proses pembuatannya, seorang yang membuat animasi atau animator harus menggunakan logika berfikir untuk menentukan alur gerak suatu objek dari keadaan awal hingga akhir objek tersebut.

\section{B. Metode Pembuatan Animasi}

Metode Pembuatan animasi Flash ini memiliki fasilitas, yaitu dimana kita bisa membuat animasi sederhana yang merupakan animasi teratur, atau juga bisa disebut animasi yang pergerakannya atau bentuknya telah kita tentukan dari awal. Berikut ini adalah jenis-jenis animasi yang ada pada flash:

1. Animasi Frame to Frame

Animasi Frame to Frame merupakan tekhnik animasi yang menampilkan gambar pada tiap frame satu persatu atau frame perframe. Prinsip dari frame to frame adalah mengganti isi dari stage pada setiap frame. Fasilitas ini digunakan untuk membentuk suatu animasi yang kompleks dimana pada setiap frame terjadi perubahan gambar.

2. Animasi Motion Tween

Animasi Motion Tween merupakan suatu animasi yang memanfaatkan fasilitas motion. Untuk membuat sebuah animasi motion sangat mudah. Anda cukup menyiapkan gambar dalam kondisi mulai bergerak di keyframe pertama dan satu lagi kondisi akhir gerakan pada keyframe terakhir, selebihnya gerakan di antara kedua keyframe tersebut akan terbentuk secara otomatis. Biasanya objek yang telah di tween pada timeline akan terlihat tanda panah berwarna biru.

3. Animasi Motion Shape.

Animasi Motion Shape adalah bentuk bisa berupa lingkaran, kotak, atau persegi yang tidak beraturan. Pada dasarnya animasi motion shape sama dengan motion tween. Perbedaannya di motion tween kita harus mensyaratkan objek berupa symbol sedangkan pada motion shape berupa shape. Jadi apabila objek tersebut berupa symbol, group, gambar atau bitmap kita harus merubahnya terlebih dahulu menjadi shape.

4. Animasi Motion Guide.

Animasi Motion Guide atau bisa dikatakan sebagai jalur gerak, merupakan suatu animasi yang pergerakkan objeknya mengikuti alur garis atau jalur yang telah kita buat.

5. Animasi Masking.

Animasi Masking ini pada prinsipnya memakai dua buah layer, dimana kita akan membuat objek yang ada di layer paling atas bisa melihat atau menembus objek yang ada di layer paling bawah. Seperti halnya sebentuk sinar yang menerangi kegelapan.

\section{Matematika Dasar}

Menurut Sulardi (2007) " matematika adalah cara berhitung dengan angka atau bilangan", tanda (+) dibaca tambah digunakan untuk penjumlahan, tanda (-) dibaca kurang digunakan untuk 
pengurangan, tanda (x) dibaca kali digunakan untuk perkalian, dan tanda (:) dibaca bagi digunakan untuk pembagian.

\section{Adobe Flash CS4}

Menurut Jibril (2011) “Adobe Flash CS4 adalah suatu program animasi grafis yang banyak digunakan para designer untuk menghasilkan karyakarya profesional". Adobe Flash CS4 sering digunakan oleh para animaator untuk pembuatan beragam animasi, seperti animasi interaktif maupun non interaktif, seperti halaman website untuk keperluan estetika, animasi kartun, presentasi, portofolio instansi, perusahaan, maupun perorangan, game, dan beberapa media animasi yang lebih banyak lagi.

Menurut Andi (2009a), Adobe Flash CS4 mempunyai beberapa keunggulan dan kecanggihan flash dalam membuat dan mengolah animasi, yaitu dapat membuat tombol interaktif dengan sebuah movie, dapat membuat objek 3D, tampilan interface yang lebih simpel dan cukup mudah dicerna, dapat merubah perubahan transparasi warna movie, mengolah animasi dari objek bitmap dapat dikonversikan ke dalam beberapa tipe data diantaranya : .swf, .html, .gif, .jpg, .png, .exe, .mov, dan masih banyak lagi keunggulankeunggulan lainnya dari flash.

\section{E. Photoshop CS4}

Menurut Hidayatullah (2009),"Adobe Photoshop CS4 adalah aplikasi profesional untuk mengolah gambar atau foto". Aplikasi ini dilengkapi dengan berbagai macam

tool dan palette untuk menampilkan dan mengedit gambar.

Fitur-fitur pada Adobe photoshop CS4 mampu menjadikan Photoshop CS4 sebagai program pengolah foto yang makin digemari oleh para desainer dan fotografer. Photoshop CS4 telah memberikan banyak kemudahan dalam hal pengolahan file, editing, dan modifikasi foto digital.

\section{F. StoryBoard}

Menurut Ees (2008)," Storyboard merupakan serangkaian sketsa yang menggambarkan suatu urutan bagian yang digunakan di dalam sebuah film". Jadi, Storyboard adalah rancangan umum suatu aplikasi yang disusun secara berurutan layer demi layer serta dilengkapi dengan penjelasan dan spesifikasi dari setiap gambar, layer, dan teks. Ini harus tetap mengikuti rancangan peta navigasi. Storyboard digunakan untuk merancang antarmuka. Antarmuka atau interface merupakan bagian dari program yang berhubungan atau berinteraksi langsung dengan pemakai (user).

Antarmuka atau interface adalah segala sesuatu yang muncul pada layer monitor pemakai (user) yang bertujuan agar program yang dihasilkan tidak terlihat rumit (harus sederhana dan tidak membingungkan), mudah digunakan untuk menarik. Hal ini harus dipikirkan oleh perancangan program karena setiap interaksi pemakai (user) dengan aplikasi harus melalui suatu antarmuka. Jadi, Storyboard merupakan rancangan kasar dari suatu tampilan layer atau merupakan gambaran umum saja.

\section{G. Struktur Navigasi}

Wijayanto (2014)"struktur navigasi adalah alur yang digunakan dalam aplikasi yang dibuat". Struktur navigasi termasuk struktur terpenting pembuatan apikasi dan gambarnya sudah ada pada tahap perancangan.

\section{HASIL DAN PEMBAHASAN}

\section{Analisa Kebutuhan Sistem}

Dalam merancang sistem yang dalam hal ini berupa multimedia interaktif, harus berpedoman pada karakteristik dan unsur yang terdapat pada multimedia interaktif yaitu:

a. Format

Program telah diubah dalam format exe sehingga pengguna hanya cukup mendouble clik saja untuk mempermudah pengguna dalam menjalankan aplikasi ini.

b. Rules

Pada aplikasi pembelajaran matematika dasar terdapat permainan yaitu evaluasi soal seperti pengurangan, penjumlahan, perkalian dan pembagian. Peraturan dalam bermain pilihan ganda adalah menjawab pertanyaan dengan benar akan mendapat point sepuluh dan salah nol. Peraturan bermain matematika dasar esai adalah cara menghitung dengan cermat dengan benar akan mendapat point sepuluh dan salah nol, sebagai contoh penjumlahan satu ditambah dengan satu sama dengan titik-titik, titik- titik tersebut diisi oleh user.

c. Scenario

Scenario dalam aplikasi ini yaitu terdiri dari lima menu utama di antaranya :

1). Materi

Dalam menu ini user akan diperlihatkan sebuah movie clip yang dimana terdapat audio yang menjelaskan tentang pengenalan angka, penjumlahan, pengurangan, perkalian dan pembagian.

\section{2). Permainan}

Terdapat dua permainan dalam menu ini, yaitu soal esai dan soal pilihan ganda. Soal Esai dalam permainan ini sebagai contoh penjumlahan satu ditambah dengan satu sama dengan titik-titik, titik-titik tersebut diisi oleh user. Permainan pilihan ganda dengan pilihan 
jawaban a,b,dan c.

3). Profil

Dalam menu ini berisi tentang animasi pembelajaran Matematika Dasar.

\section{4). Bantuan}

Dalam menu ini menerangkan dan menjelaskan fungsi dari button-button.

\section{5). Keluar}

Sebelum keluar aplikasi ini akan muncul pesan "Anda Yakin Ingin Keluar ?" dengan pilihan jawaban "iya" atau "tidak".

\section{Setting dan Sinopsis}

Terdapat lima menu utama yang dibuat peneliti untuk mempermudah pembelajaran matematika dasar. Aplikasi pembelajaran matematika dasar ini memiliki scenario dan alur cerita sebagai berikut. Program animasi ini diawali dengan loading, yang langsung menuju halaman judul. Di dalam halaman judul akan ada button untuk memasuki halaman menu utama. Di dalam halaman menu utama terdapat lima button, yaitu button materi, button permainan, button profil, button bantuan dan button keluar. Dalam button materi terdapat halaman menu pengenalan angka, pengenalan penjumlahan, pengenalan pengurangan, pengenalan perkalian, dan pengenalan pembagian. Dalam button profil menampilkan biodata dan ucapan dari peneliti. Sedangkan button permainan terdapat sub menu yaitu halaman menu permainan yang terdiri dari dua pillihan permainan seperti soal esai dan pilihan ganda.

\section{a. Desain Aplikasi}

Alur permainan dalam Perancangan Animasi Interaktif Pembelajaran Matematika Dasar adalah :

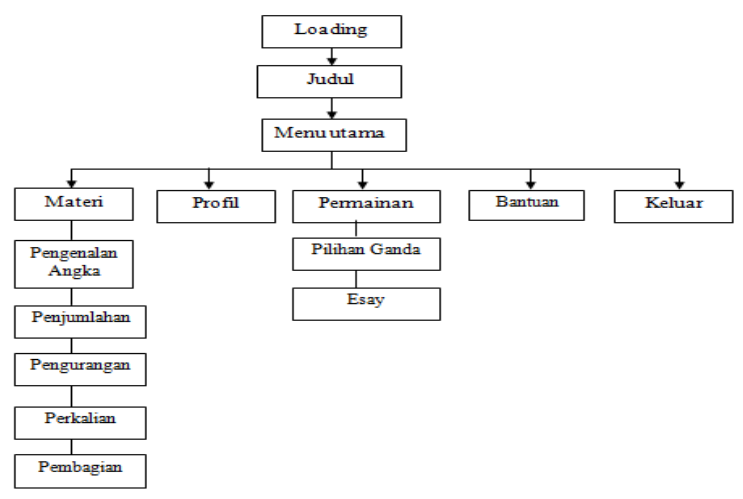

Uallual 111. 1 Alul Utalla resallcallyall

Animasi Interaktif Pembelajaran Matematika

Dasar

Animasi Interaktif Pembelajaran Matematika Dasar ini dibuat dalam bentuk form yang dipecah dalam beberapa bagian guna membagi keterangan aplikasi yang akan dikerjakan secara rinci. Rincian keterangan ini mempermudah dalam proses pembuatan aplikasi. Secara lengkap desain aplikasi dibuat dalam story board seperti tampilan dibawah ini :

\section{1). Halaman Menu Utama}

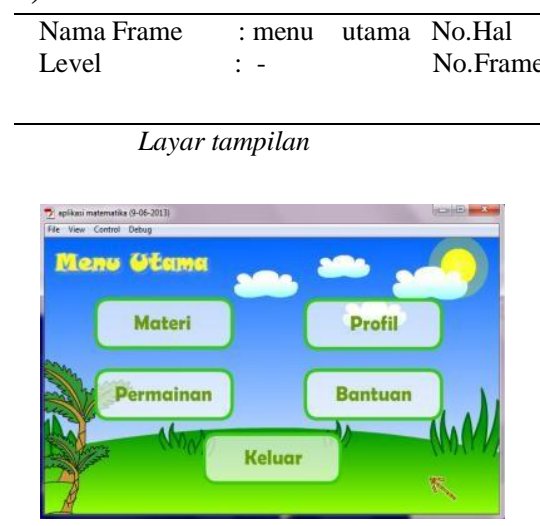

No.Hal

Keterangan tampilan

Menu utama terdiri dari :

- Materi :

menampilkan materi

belajar

- Permainan :

menampilkan permainan

soal

- Profil : menampilkan

biodata dan ucapan

- Bantuan :

menampilkan bantuan

dalam menjalankan

program

- Keluar

keluar program

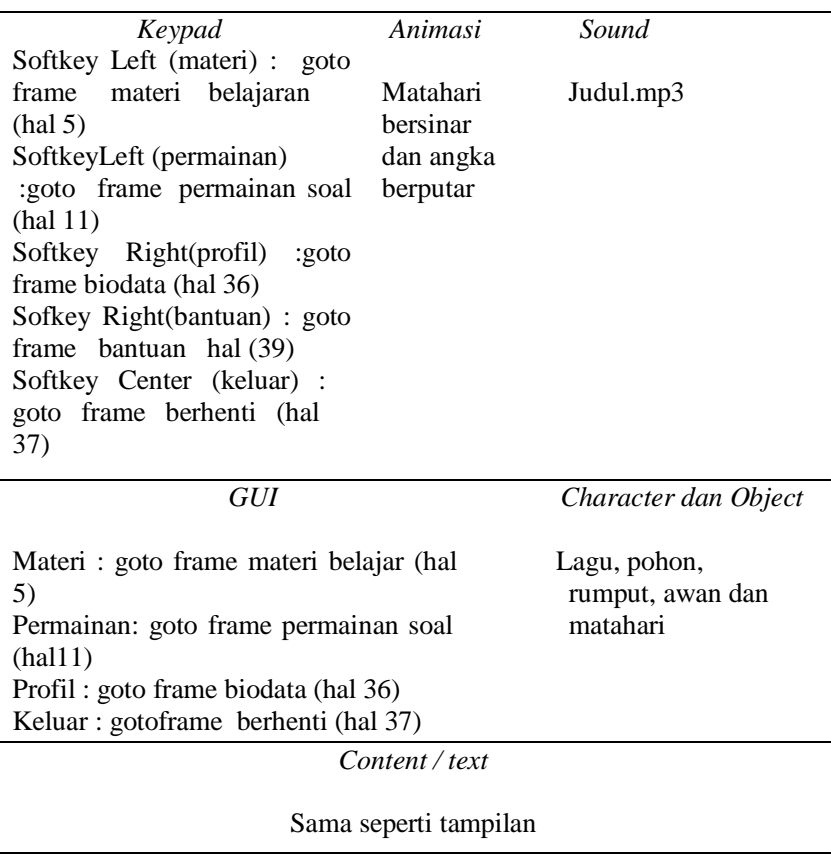

Gambar III.2 Story Board

Halaman Menu Utama 


\section{2). Halaman Materi}

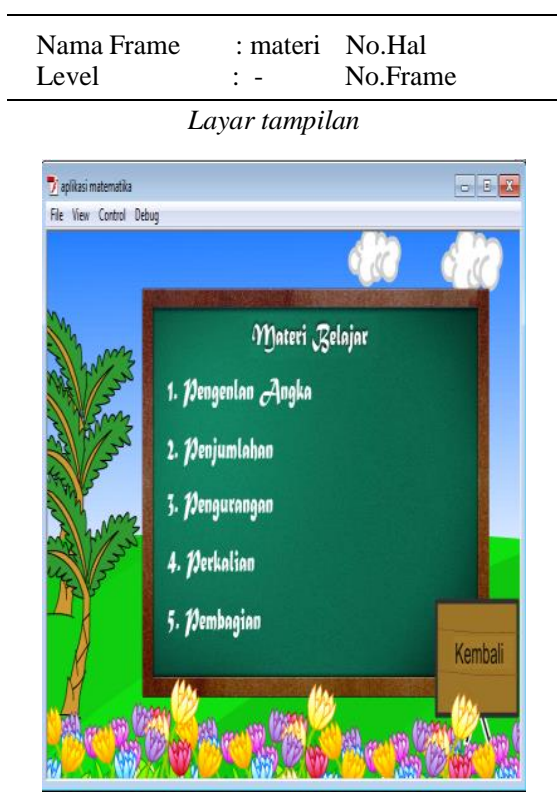

$: 5$

Keterangan
tampilan
pengenalan
angka:
menampilkan angka
dan suara.
penjumlaha
menampilkan
pengertian penjumlahan
dan contoh.
Pengurangan :
menampilkan
pengertian pengurangan
dan contoh. Perkalian :
menampilkan
pengertian perkalian
dan contoh.
Pembagian
menampilkan pengertian
pembagian dan

cont

oh.

Kembali : kembali

ke menu utama

\begin{tabular}{ccc}
\hline Keypad & Animasi & Sound \\
& Bunga & Tidak \\
$\begin{array}{l}\text { Softkey Left (Pengenalan } \\
\text { angka) : goto frame angka }\end{array}$ & bergoyang & ada
\end{tabular}

. goto frame angk

dan suara (hal 6) Softkey

Left (Penjumlahan) : goto

frame penjumlahan dan

contoh (hal 7)

Softkey Left

(Pengurangan) : goto

frame pengurangan dan

contoh (hal 8)

Softkey Left (Perkalian) :

goto frame perkalian dan

contoh (hal 9)

Softkey Left (Pembagian)

: goto frame pembagian

dan contoh (hal 10)

Softkey Right (kembali) :

goto frame materi belajar

(hal 5

\section{GUI}

-Pengenalan angka: goto frame angka dan suara (hal 6)

-Penjumlahan : goto frame penjumlahan dan contoh (hal 7)

-Pengurangan : goto frame pengurangan

dan contoh (hal 8)

-Perkalian : goto frame perkalian dan

contoh (hal 9)

-Pembagian : goto frame pembagian dan

contoh (hal 10)

- Kembali : goto frame materi belajar (hal 5)

\section{Content / \\ text}

Sama seperti tampilan
Character dan Object

Pohon, bunga,papan tulis dan awan

\section{3). Halaman Perkalian}

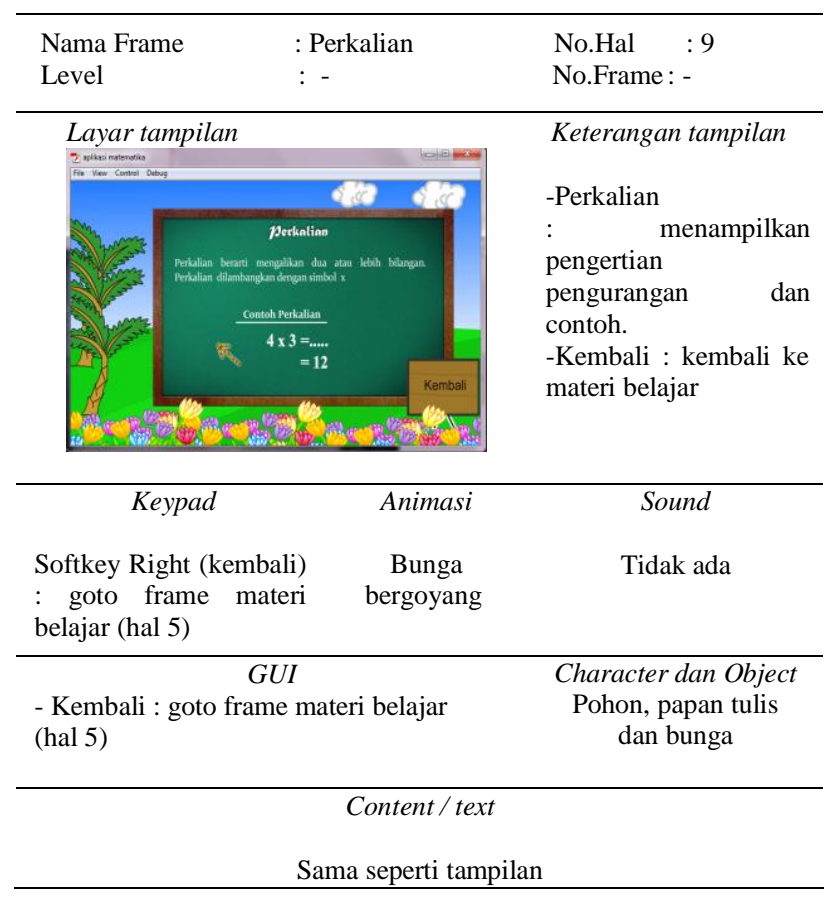

\section{4). Halaman Permainan}

\begin{tabular}{llll}
\hline Nama Frame & : permainan & No.Hal & $: 23$ \\
Level & $:-$ & No.Frame & $:-$ \\
\hline
\end{tabular}

Layar tampilan
Keterangan tampilan
Keypad

Gambar III.5 Story Board Halaman Permainan

Gambar III.3 Story Board Halaman Materi 


\section{Testing Program}

Dalam pembuatan perancangan animasi interaktif pembelajaran matematika dasar tersebut dilakukan wawancara langsung dengan anak-anak dan orang tua mengenai program yang telah dibuat. Kuesioner diberikan kepada 5 anakanak antara kelas satu sampai tiga sekolah dasar tentang bagaimana pendapat mereka setelah aplikasi ini dijalankan, yang terdiri dari 10 pertanyaan.

Berikut ini adalah bagan dari Kuesioner Perancangan Animasi Interaktif Pembelajaran Matematika Dasar untuk anak-anak sekolah dasar :

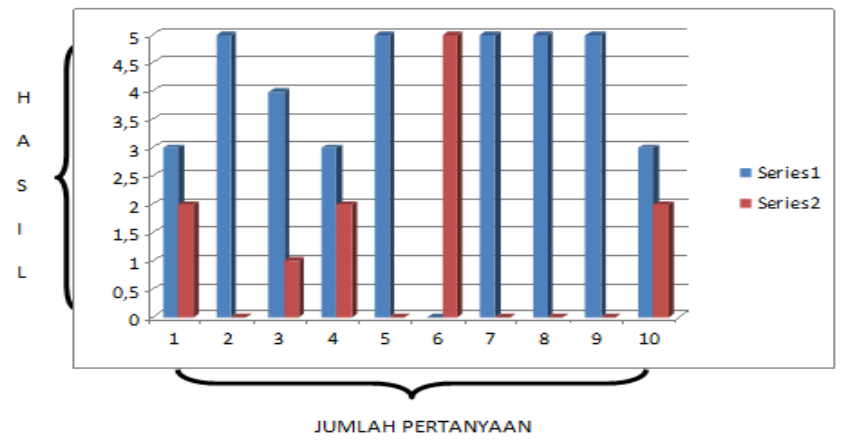

Gambar III.6 Tampilan Grafik kuesioner anak-anak sekolah dasar

\section{KESIMPULAN}

Dari pembahasan mengenai Animasi Interaktif Pembelajaran Matematika Dasar untuk anak-anak menggunakan Adobe CS4 peneliti menyimpulkan bahwa :

1. Diharapkan dengan adanya animasi interaktif ini bagi anak-anak sedkolah dasar kelas satu sampai kelas tiga tidak cepat bosan dalam belajar dan dapat menumbuhkan minat belajar.

2. Dengan metode belajar baru yang bermunculan sekarang, membuat kita dapat memilih cara belajar menurut selera kita masing-masing. Salah satu diantaranya dengan pembelajaran animasi interaktif berbasis teknologi informasi yang memiliki banyak keunggulan dari metode belajar lain seperti tidak membuat jenuh.

3. Oleh karena itu peneliti berharap pembelajaran animasi interaktif ini dapat mengakomodir para pelajar khususnya anak tingkat sekolah dasar dan umum untuk dapat meningkatkan minat belajar dengan sebuah terobosan baru guna mengurangi kekurangan cara belajar biasa.

4. Dengan pembuatan animasi interaktif ini dapat mengetahui bagaimana proses pembuatannya, karakter yang digunakan dalam permainan, cara melakukan publish terhadap suatu animasi, penggunaan Action Scirpt sehingga dapat menampilkan Frame, Movie Cliep dan membuat gambar bergerak dan berubah-rubah.

\section{REFERENSI}

Andi. (2009a). Adobe Flash CS4 Untuk Pemula. Yogyakarta: CV. Andi Offseet.

Andi. (2009b). Seri Panduan Lengkap: Adobe Flash CS4 Profesional. Yogyakarta: CV. Andi Offseet.

Ees. (2008). Membuat Animasi Kartun Dengan Macromedia Flash 8. Jakarta: D@takom Lintas Buana.

Hidayatullah, T. (2009). 45 Menit Belajar Photoshop CS4. Yogyakarta: Mediakom.

Jibril, A. (2011). Jurus Kilat Adobe Flash. Jawa Barat: Dunia Komputer.

Sulardi. (2007). Pandai Berhitung Matematika. Jakarta: Erlangga.

Wijayanto, R. (2014). PERANCANGAN ANIMASI INTERAKTIF PEMBELAJARAN BAHASA INGGRIS UNTUK KELAS 2 PADA MI NURUL FALAH CIATER. Evolusi, II(1), 111. Retrieved from http://ejournal.bsi.ac.id/ejurnal/index.php/evol usi/article/view/654

\section{PROFIL PENULIS}

Siti Kusnul Wulandari. Kelahiran: Kulon Progo, 17 Januari 1986 Saat ini menjadi Karyawan di PT Maxxima Innovative Engineering. Telah menyelesaikan pendidikan Diploma Tiga (D-3) dengan gelar A.Md pada tahun 2013.

Eka Rini Yulia, M.Kom. Kelahiran: Jakarta, 08 Juli 1988. Saat ini menjadi staff pengajar di STMIK Nusa Mandiri Jakarta. Telah menyelesaikan pendidikan S1 dengan gelar S.Kom Kom pada tahun 2012 dan pendidikan S2 dengan gelar M.Kom pada tahun 2015 di STMIK Nusa Mandiri Jakarta. 